\title{
ЗАРУБІЖНИЙ ДОСВІД РЕГЛАМЕНТАЦІї КРИМІНАЛЬНОӤ ПРОЦЕСУАЛЬНОЇ ДІЯЛЬНОСТІ АДВОКАТА-ПРЕДСТАВНИКА ПОТЕРПІЛОГО
}

\author{
СМЕЛЬЯНОВ Роман Олександрович - викладач кафедри організації \\ досудового розслідування факультету № 1 Криворізького навчально-наукового \\ інституту Донецького юридичного інституту МВС України
}

УДК 343.121.4

DOI 10.32782/LAW.2020.3.19

В умовах реформування кримінального процесуального провадження загалом та адвокатури, зокрема, пріоритетність захисту як правового інституту важко перебільшити, адже саме завдяки його реалізації забезпечується всебічний розвиток демократії, дотримання прав та свобод особи, рівноправність, змагальність, справедливе правосуддя та досягнення істини у справі. На сьогодні триває процес формування правового та організаційного забезпечення засади забезпечення права на захист, який є пріоритетним напрямком державної політики України.

В умовах побудови правової держави актуальною для науки кримінального процесу і практики законотворення є захист прав потерпілого, процесуальний статус якого в умовах чинного законодавства менш досконалий, ніж підозрюваного, обвинуваченого. Декларуючи те, що призначення кримінального процесуального законодавства, перш за все, полягає у захисті потерпілих від кримінального правопорушення, законодавець, е дійсності, на перше місце ставить захист інтересів підозрюваного та обвинуваченого.

Однак, на ефективне поновлення прав та законних інтересів осіб, потерпілих від злочину орієнтують і сучасні міжнародні документи. Це зумовлюе необхідність реформування національного законодавства, що стосується потерпілого та його представника, з метою приведення його у відповідність зі світовими стандартами в галузі прав людини і громадянина. Слід відмітити, що діяльність адвоката-представника потерпілого у кримінальному процесі визначена тільки в найзагальніших рисах, без конкретизації прав та обов'язків. Далеко не всі проблемні питання у цьому напрямі належним чином вивчені, а деякі базуються на застарілому законодавстві й узагальненні слідчої та судової практики минулих років; не проаналізовані особливості зарубіжного досвіду участі адвоката-представника потерпілого на різних стадіях кримінального процесу.

Так, у ст. 1 Закону України «Про адвокатуру та адвокатську діяльність» зазначено, що адвокатом є фізична особа, яка здійснює адвокатську діяльність на підставах і в порядку, що передбачені законом. Адвокатська діяльність - це незалежна професійна діяльність адвоката щодо здійснення захисту, представництва та надання інших видів правової допомоги клієнту. Термін «представництво» визначено як вид адвокатської діяльності, що полягає в забезпеченні реалізації прав і обов’язків клієнта в цивільному, господарському, адміністративному та конституційному судочинстві, в інших державних органах, перед фізичними та юридичними особами, прав і обов'язків потерпілого під час розгляду справ про адміністративні правопорушення, а також прав і обов'язків потерпілого, цивільного позивача, цивільного відповідача у кримінальному провадженні [1]. Представництво адвокатом інтересів потерпілого у кримінальному судочинстві є основним засобом захисту його прав та законних інтересів. 


\section{Кримінальне право, кримінальний процес та криміналістика}

Системи кримінального судочинства більшості країн Европи і Північної Америки стосовно ролі і обсягу процесуальних прав потерпілого можна поділити на дві основні групи.

До першої групи відносяться країни, що використовують англосаксонську модель кримінального судочинства (Великобританія, Ірландія, США, Канада), законодавство яких не знає такої кримінально-процесуальної фігури як потерпілий. Наслідком цього є практично повна відсутність норм, регулюючих положення потерпілого у кримінальному процесі. У той же час, у цих країнах приділяється значна увага створенню ефективної системи соціального захисту і допомоги жертвам злочинів, а в останні два десятиліття в наявності і тенденція до помітного підвищення правового статусу жертв злочинів, до визнання необгрунтованої орієнтації на пріоритетну увагу до прав обвинувачених за рахунок збитків інтересам жертв [2, c. $96 ; 3]$.

До другої групи відносяться держави континентальної системи кримінального судочинства, де законодавство традиційно дає потерпілому право брати участь у кримінальному переслідуванні винного.

Розгляд правового статусу жертви 3лочину почнемо з Великобританії, оскільки їі кримінально-процесуальне право є найстарішою процесуальною системою світу. Дійсно, потерпілі в цій країні не мають жодного особливого статусу в системі кримінального правосуддя. До недавнього часу їх навіть не інформували про порушення кримінального переслідування. Жертва злочину розглядається як звичайний громадянин, зобов’язаний свідчити, сприяти поліції. Свідчення потерпілого потрібні лише в тих випадках, коли за наявності спірних моментів вони можуть сприяти судовому розгляду. У цьому випадку потерпілий зобов'язаний як свідок звинувачення відповідати на питання звинувачення і захисту. Тому систему правосуддя у Великобританії часто називають несприятливою для потерпілого.

У Англії і Уельсі представниками професії є баррістери («barristers» або радники «counsels») - це адвокати, які мають право виступати у вищих судових інстанціях. До їх повноважень належать такі: складання процесуальних документів (деталізованих позовних вимог або відкликання позову); консультування 3 питань права; представлення інтересів у суді. Адвокати не уповноважені: отримувати інструкції від клієнтів; займатись процесом розкриття інформації; спілкуватись зі свідками; проводити розслідування та керувати ними; займатись досудовим/позасудовим вирішенням спорів.

Соліситори («solicitors») - юристи, до чиїх функцій належать: отримувати інструкції/ доручення від клієнта; визначати відповідні норми англійського права; за необхідності, визначати адвоката, який спеціалізується у певній галузі права; давати інструкції адвокату; готувати та передавати позов до суду; вивчати можливості захисту щодо позову, поданого проти клієнта; отримувати інструкції від клієнта щодо захисту, відкликання позову; давати консультації щодо подальших дій і заяв, які можуть бути подані до винесення рішення судом; займатись процесом розкриття інформації та ознайомлення 3 нею; отримувати інструкції/доручення для підготовки письмових заяв свідків, для проведення інтерв'ю зі свідками; визначати експертів і давати інструкції експертам; готувати справу до слухання у суді; вести переговори про досудове/позасудове врегулювання спору [3, с. 28].

Ці юристи також за бажанням можуть отримати більш широкі повноваження [4, c. 10-11]. Зазначені суб'єкти мають право брати участь у кримінальному провадженні як захисники, проте для солісіторів обмеженим є право на публічні виступи в судах.

Стан справ у цій сфері фактично почав змінюватися лише з 22 лютого 1990 року, коли уряд опублікував «Хартію жертв злочинів» (Викладення прав жертв злочинів). У цьому документі, що є типовою програмоюпам'яткою для потерпілих, детально перераховані обов'язки всіх відомств, пов'язаних iз провадженням правосуддя, по відношенню до жертв злочинів. Проте положення Хартії стосуються питань забезпечення безпеки, інформаційного забезпечення і соціальної допомоги особам, постраждалим від злочинних посягань. Будь-яких помітних 
змін їх процесуального статусу доки не відбулось.

Значно далі в цьому напрямі просунулися СIIA, де, також як і у Великобританії, до початку 70-х років XX століття роль потерпілого зводилася до надання свідчень, необхідних для засудження винного. Потерпілі фактично були позбавлені будь-яких прав у процесі i, у свою чергу, стали розглядати кримінальний процес не лише як такий, що не відповідає їх вимогам, але взагалі байдужий до них.

Суспільний рух на підтримку прав жертв злочинів, що різко активізувався в кінці 1950-х років, зростання злочинності в країні, перш за все насильницької, розвиток віктимологічних досліджень і усвідомлення недосконалості сучасної системи кримінального правосуддя ініціювали послідовну діяльність урядів США і штатів, направлену на істотне розширення прав потерпілих.У процесі цього в Сполучених Штатах були прийняті десятки законів, що розширюють кримінально-процесуальні права потерпілих від злочинів [5, с. 10].

У кримінальному процесі США право адвоката представляти інтереси підозрюваного, обвинуваченого закріплено для всіх стадій. Це передбачено у VI Поправці Конституції США, Федеральному кримінальному процесуальному законодавстві, законодавстві штатів, прецедентах Верховного суду США и Верховних судів штатів. Проте, чіткого переліку прав захисника законодавець не пропонує.

Як зазначають дослідники, проблем участі захисника в стадії досудового розслідування у кримінальному процесі США, законодавчі норми і судові прецеденти надали такі основні права захиснику підозрюваного, обвинуваченого: 1) виступити на захист інтересів клієнта з моменту його затримання або арешту; 2) бачитися і консультувати свого клієнта до проведення допиту, а також протягом усього поліцейського розслідування; 3) брати участь у процедурі проведення допиту підзахисного, його впізнанні і обшуку; 4) ознайомитися 3 матеріалами обвинувачення; 5) заявляти клопотання, пов’язані 3 наданням доказів, реалізацією прав підзахисного та ін. Характер досудового роз- слідування в кримінальному процесі США, притаманна йому змагальність впливає на можливості адвоката при здійсненні захисту інтересів свого клієнта.

Захистом підозрюваних, обвинувачених на стадії досудового розслідування в СШІА можуть займатися як адвокати - члени колегії адвокатів, так і адвокати, які отримали ліцензію на ведення індивідуальної адвокатської практики [6, с. 12-15; 7, с. 355].

Історичним американські юристи вважають 1982 рік, коли Конгрес США прийняв Білль про захист жертв і свідків злочинів [8]. Це перший закон на федеральному рівні, що закріпив права жертв на участь у судовому процесі, а також їх права на захист і допомогу. Згідно з цим законом, потерпілі від злочинів, передбачених федеральним законодавством, мають такі права: на справедливе звернення з повагою до гідності і приватного життя потерпілого; на необхідний захист від правопорушника; бути сповіщеним про судові процедури; бути присутнім при всіх прилюдних судових процедурах, за винятком тих випадків, коли суд визначить, що на показання потерпілого можуть вплинути свідчення у суді інших осіб; на консультацію із прокурором, що підтримує обвинувачення у справі; на здобуття реституції; на інформацію про обвинувачення, вирок, висновок і звільнення правопорушника.

У цілому законодавство США розвивається у напрямі неухильного розширення прав жертв злочину і посилення гарантій їх реалізації. Що ж до інституту представництва у процесі інтересів жертв злочину, то таке право у США (втім, як і у Великобританії) визнавалось історично. При цьому, законодавством не регламентується процесуальний статус представників потерпілих як такий, та в цьому і немає необхідності, оскільки як адвокат, так і аторней, представляючи у процесі інтереси жертви, займають однакове процесуальне положення обвинувача зі всіма його широкими можливостями.

Класичною формою континентального змішаного кримінального процесу є кримінальний процес Франції. У цей час там діє Кримінально-процесуальний кодекс 1958 року з подальшими змінами і доповненнями $[9$, с. 323]. 


\section{Кримінальне право, кримінальний процес та криміналістика}

у французькому кримінально-процесуальному законодавстві поняття «потерпілий» і «цивільний позивач» 6 синонімами. А. I. Аубенський звертає увагу, що «пред'явлення цивільного позову передбачає обов'язкове порушення кримінального переслідування. Такого роду цивільний позов може не містити вимоги про стягнення будь-якого матеріального блага» [10, с. 125]. Отже, у Франції під терміном «цивільний позов (action civile)» розуміється кримінальний позов, порушений за ініціативою приватної особи, на відміну від прилюдного позову (action publique), що порушується ех officio прокуратурою.

Вивчення правових актів, що регулюють діяльність адвокатів у Франції, показало, що законодавець не тільки визначив вимоги до адвокатів, а й передбачив кримінальну відповідальність за їх недотримання. Так, відповідно до ст. 433-17 КК Франції кримінальна відповідальність настає, якщо інша, не передбачена міжнародними угодами, особа, яка не зареєстрована належним чином у реєстрі колегії адвокатів і при цьому здійснює діяльність, що належить до виключної компетенції адвоката. За цією статтею кваліфікуються також дії особи, яка незаконно використовує статус і не відповідає встановленим для його набуття вимогам, 3 метою ввести в оману необмежене коло осіб щодо свого права на статус та належність до професії. Примітно, що у кримінальному процесуальному кодексі Франції законодавець детально не визначає підстави участі адвоката у кримінальному процесі, порядок його залучення та ін. Ці положення певним чином відображені у спеціальному законодавстві (Закон № 71-1130 від 31 грудня 1971 року «Про реформу низки судових і юридичних професій», Декрет № 91-1197 від 27 листопада 1991 року «Про адвокатуру і адвокатську діяльність», Закон № 2005-790 від 12 липня 2005 року «Про правила професійної етики адвоката», Нормативне рішення № 2005-003 «Про затвердження регламенту адвокатури і адвокатської діяльності у Франції»).

Цікаво, що французька процесуальна теорія абсолютно не розрізняє захисника обвинуваченого і представника потерпілого як самостійні суб'єкти кримінального процесу [11].

У Франції не відомий інститут ознайомлення сторін зі всіма матеріалами справи після закінчення досудового розслідування першої інстанції, проте, це не обмежує права сторін, оскільки ознайомлення зі справою відбувається при провадженні деяких слідчих дій, а крім того, у сторін є можливість повністю ознайомитися зі справою під час попереднього слідства другої інстанції (ст. 197 КПК).

Повноваження цивільного позивача за французьким кримінально-процесуальним законодавством залежать від того, у якому складі суду розглядається кримінальна справа: у суді присяжних, виправному трибуналі або поліцейському трибуналі.

Велика увага регламентації процесуального положення потерпілого і його представника приділена у Кримінально-процесуальному кодексі ФРН, прийнятому 1 ^ютого 1877 року і що діє в редакції від 7 квітня 1987 року. Досить сказати, що П'ята книга КПК ФРН повністю присвячена участі у процесі потерпілого (всього КПК ФРН складається із семи книг). У кримінальному процесі ФРН законодавець не обмежує коло захисників професійними адвокатами. Як захисники можуть брати участь адвокати, а також викладачі юриспруденції у німецьких вищих навчальних закладах згідно 3 Рамковим законом про вищі навчальні заклади, що мають кваліфікацію для обіймання посади судді. Інші особи можуть бути захисниками лише за умови затвердження судом. Якщо у випадку обов'язкової участі захисника обрана особа, що не належить до осіб, які можуть бути призначені захисником, вона може бути допущена у якості захисника за вибором лише поряд із особою, яка може бути призначена захисником [12].

Участь потерпілого у кримінальному судочинстві передбачено у трьох формах: як обвинувач у справах приватного обвинувачення, співобвинувача у справах прилюдного обвинувачення і цивільного позивача. Так, відповідно до $\$ 374$ КПК ФРН потерпілий може порушити розслідування у порядку приватного обвинувачення без попереднього звернення у прокуратуру у справах 
про недоторканість житла, службових приміщень (§ 123 КК ФРН), про образу (§§ 185 187 К КК), якщо образа не стосується жодної 3 політичних організацій, про порушення таємниці листування (§ 202 КК), про тілесні ушкодження (§§ 223, 223a, 230 КК), про загрозу і іншим злочинам, спеціально визначеним в абз. 1 § 374 КПК ФРН.

У КПК ФРН також передбачені випадки обов'язкової участі захисника, а саме: якщо справа у першій інстанції розглядається земельним Верховним судом або земельним судом; обвинуваченому пред'являється обвинувачення в учиненні кримінального злочину (в інших випадках голова призначає захисника за клопотанням або за офіційною ініціативою, якщо участь захисника убачається доцільною у зв'язку із тяжкістю діяння або складністю фактичної або юридичної сторони справи або якщо очевидно, що обвинувачений не може захищати себе сам, а саме, оскільки для потерпілого призначений адвокат); провадження може призвести до заборони зайняття професійною діяльністю; у відношенні обвинуваченого виконується попереднє ув'язнення; обвинувачений знаходиться у закладі виконання покарання не менше трьох місяців на підставі попередньої або наступної постанови суду і не звільнений не менше, ніж за два тижні до початку судового розгляду; для підготовки експертного висновку про психічний стан обвинуваченого можливе поміщення обвинуваченого до психіатричної клініки; здійснюється провадження щодо неосудних і процесуально недієздатних осіб; попередній захисник звільнений від участі у провадженні судовим рішенням [11]. Це узгоджується із Федеральним Положенням про адвокатуру, у якому передбачено, що адвокат повинен здійснювати захист або діяти як помічник, якщо його призначено захисником або помічником відповідно до положень Кримінально-процесуального кодексу, Закону про адміністративні правопорушення, Закону про міжнародну правову допомогу у кримінальних справах або Закону про взаємодію із Міжнародним кримінальним судом (§ 49) [13].
Зауважимо, що відповідно до § 397 а КПК ФРН потерпілому, промовцеві як співобвинувачеві має бути надана допомога у запрошенні адвоката, якщо справа є складною з правового і фактичного погляду, а потерпілий не може достатньою мірою забезпечити свої інтереси або зробити це йому не під силу. Адвокат запрошується головою, причому потерпілому протягом певного терміну надається можливість вибрати адвоката. Голова призначає названого потерпілим, адвоката його представником, якщо для відмови в цьому немає серйозних підстав. Рішення суду про надання допомоги потерпілому оскарженню не підлягає. Потерпілий має право принести термінову скаргу на визначення, яким було відмовлено у відкритті судового розгляду (стадія віддання під суд) або яким було припинено провадження у справі. КПК ФРН дозволяє потерпілому оскаржити такі визначення незалежно від того, оскаржив їх прокурор чи ні (§ 401).У той же час співобвинувач не може оскаржити вирок із метою, щоб за вчинення діяння засудженому було призначено інше покарання (§ 400 КПК).

Як цивільний позивач потерпілий також може скористатися послугами адвоката (§ 404 КПК). Потерпілий отримує копію вироку або виписку з нього (§ 406), проте позбавлений права оскаржити вирок, яким йому відмовлено у відшкодуванні заподіяної шкоди (§ 406 а КПК).

Законодавство ФРН детально регламентує і процесуальний статус адвоката-представника потерпілого. Глава 4 П'ятої книги КПК ФРН, хоча і іменується «Інші повноваження потерпілого», практично повністю присвячена повноваженням адвоката-представника потерпілого.

Згідно з § 406 е адвокат від імені потерпілого має право знайомитися 3 матеріалами справи, які передані до суду або підлягали 6 передачі до суду в разі порушення публічного переслідування, а також оглянути речові докази. У передбачених законом випадках у цьому праві адвокатові може бути відмовлено, наприклад, якщо таке ознайомлення загрожує цілям досудового розслідування або пов'язано з істотним затягуванням процесу. За клопотанням адвоката матеріали справи 


\section{Кримінальне право, кримінальний процес та криміналістика}

можуть бути навіть видані йому на руки, за винятком речових доказів, для ознайомлення 3 ними в адвокатській конторі. Відмова у задоволенні такого клопотання може наступити лише за наявності серйозних на те заперечень. На досудових стадіях процесу питання про ознайомлення адвоката потерпілого $з$ матеріалами справи вирішує прокуратура, але ії відмова може бути оскаржена до суду. Адвокат може знімати копії з документів, що знаходяться у матеріалах справи.

Під час допиту потерпілого у суді або прокуратурі має бути забезпечена участь його адвоката ( $\$ 406$ f). Він може заперечувати проти питань, що ставляться потерпілому (абз. 2 § 238, § 242) і клопотати з відома потерпілого про проведення закритого слухання справи.

Закон передбачає однакові наслідки нез'явлення адвоката - захисника і адвоката-представника потерпілого (§§ 145, 406 d КПК ФРН).

Отже, кримінально-процесуальне законодавство ФРН детальніше, ніж законодавство Франції визначає правовий статус адвоката-представника потерпілого і на відміну від останнього наділяє його такими процесуальними правами, які відсутні в особи, що представляється.

Законодавство інших країн континентальної Европи також приділяє велику увагу процесуальному статусу потерпілого і його представника.

У ст. 47 КПК Естонії зазначено, що адвокат-захисник має такі права: одержувати документи від фізичних та юридичних осіб, необхідні для надання юридичної допомоги людині, яка захищається; подавати докази; представляти запити і скарги; брати участь у процесуальних діях і робити заяви про умови, хід та результати процесуальних дій; використовувати технічні засоби при виконанні обов'язку захисту, якщо це не ускладнює проведення процесуальних дій; брати участь у процесуальних діях, виконуваних у присутності підзахисного на досудовій та судовій стадії; після вступу в справу вивчати протокол допиту підзахисного і документи про затримання підзахисного, а після завершення попереднього розслідування справи вивчати всі матеріали, наявні в справі; мати побачення 3 підзахисним без присутності інших людей необмежену кількість разів і 3 необмеженою тривалістю, якщо інше не передбачено КПК. У ст. 45 КПК Естонії зазначено, що адвокат має право вступити в кримінальну справу з моменту, коли особа набуває статусу підозрюваного. Відповідно до п. 2 ч. 1 ст. 72 КПК Естонії адвокат має право відмовитися давати показання як свідок про обставини, які стали йому відомими у зв'язку з наданням юридичної допомоги [14].

Так, жертва злочину у кримінальному процесі Австрії може брати участь як приватний обвинувач, а у справах публічного обвинувачення як потерпілий (у звичному для нас розумінні це цивільний позивач) i субсидіарного обвинувача (у разі заявленого ним клопотанням про переслідування особи при відмові від цього прокуратури). У всіх цих випадках потерпілий визнається стороною обвинувачення і може мати адвоката-представника, процесуальні права якого визнаються рівними правам того, що представляється (\$ 50 КПК Австрії). Низкою останніх змін і доповнень до КПК Австрії 1975 року потерпілий отримав можливість брати участь у слідчих діях і оскаржити рішення компетентним органам [15, c. 229].

у законодавстві Нідерландів і Швеції передбачено право потерпілого на надання йому безкоштовної юридичної допомоги. Аналогічні положення містяться у проєкті закону про надання допомоги потерпілим, представлено Міністерством юстиції Швейцарії.

Підводячи підсумок порівняльному дослідженню кримінального процесуального законодавства сучасних зарубіжних держав, слід визнати, що спільними рисами законодавства України й деяких зарубіжних країн $\epsilon$ наявність норм, що передбачають: визначення особи, яка може бути захисником у кримінальному процесі; вимоги на підтвердження повноважень захисника; обов'язки i права захисника; порядок залучення захисника; випадки обов'язкової участі захисника; умови відмови, заміни, відсторонення захисника; можливість призначення захисника, порядок і умови такого призначення. 
Залежно від структури кримінального процесу (відсутність стадії досудового розслідування), повноваження адвоката суттєво різняться.

Системи кримінального судочинства більшості країн Европи і Північної Америки стосовно ролі і обсягу процесуальних прав потерпілого поділяються на дві основні групи - англосаксонська модель кримінального судочинства (Великобританія, Ірландія, CIIA, Канада) та континентальна системи кримінального судочинства (Франція, ФРН). Зміцнення процесуального статусу потерпілого i його представника 6 новітньою загальносвітовою тенденцією. Розвинені держави бачать вирішення проблеми захисту прав жертв злочину не в останню чергу в консультуванні і наданні їм юридичної допомоги. При цьому у цих країнах по-різному підходять до визначення процесуального статусу адвоката-представника потерпілого. Найчастіше його процесуальні можливості визнаються ідентичними процесуальним правам того, що представляється (Франція, Австрія). Виключення складає кримінально-процесуальне законодавство ФРН, де адвокат-представник потерпілого має особливий статус, що включає ряд важливих повноважень, які відсутні у самого потерпілого.

\section{Література}

1. Про адвокатуру та адвокатську діяльність : Закон від 5 лип. 2012 р. № 5076 VI. Верховна Рада Украӥни. URL: https://zakon. rada.gov.ua/laws/show/5076-17\#Text

2. Квашис В. Е., Вавилова $\lambda$. В, Зарубежное законодательство и практика защиты жертв преступлений. Москва : Издво МВД РФ, 1996. 256 с.

3. Михайловская И. Б. О положении личности в англо-американском уголовном процессе. Москва : Госюриздат, 1991. 199 с.

4. Навыки адвоката: Сборник материалов проекта «Профессиональное развитие адвокатов в ведении уголовных дел по экономическим преступлениям» (российский и британский опыт) / авторысоставители: А. Б. Гутников, С. В. Краузе, Ю. Н. Хапалюк. Серия «Права человека. СПб, 2014. 124 с.
5. Парий А. В. Потерпевший от преступления на досудебных стадиях уголовного судопроизводства США (сравнительно-правовое исследование) : монография. Волгоград, 2007. 110 с.

6. Курдова А. В. Защитник обвиняемого в уголовном процессе США: Досудебная стадия: автореф. ... канд. юрид. наук: 12.00.09. Москва, 1998. 19 с.

7. Дубівка I. В. Правова регламентація участі захисника в кримінальному процесі за законодавством зарубіжних країн. Юридичний часопис Національної академіӥ внутрішніх справ. 2017. № 1 (13). С. 350-360.

8. Міжнародний білль про права людини. Виклад фактів / Харківська правозахисна група. Харків : Фоліо, 2004. 62 с.

9. Уголовно-процесуальный кодекс Франции 1958 года / пер. с франц., предисл. С. В. Боботоваи, В. И. Каминской. Москва, «Прогресс», 2005. 438 с.

10. Аубенский А. И. Реформа уголовного процесса во Франции (19571959 гг.): дисс. ... канд. юрид. наук : 12.00.09. Спб, 2002. 218 с.

11. Основні акти, які регулюють адвокатуру і адвокатську діяльність у Франції. URL: http://cnb.avocat.fr/

12. Кримінальний процесуальний кодекс Федеративної Республіки Німеччина - Strafprozessordnung (StPO). URL: http:// pub.ub.uni-potsdam.de/volltexte/2012/6177.

13. Федеральне положення про адвокатуру у редакції із виправленнями, опубліковане у Частині III Федерального вісника законів, реєстраційний номер 303-8 із змінами, внесеними статтею 7 Закону від 10 жовтня 2013 року (Федеральний вісник законів), ч. 1, стор. 3786 . URL: unba.org.ua>assets $>$ bundesrechtsanwaltsordnung-ukr.

14. Кримінально-процесуальний кодекс Естонії від 30 грудня 2004 року. URL: https://www.riigiteataja.ee/aNt/1331 1874?leiaKehtiv

15. Банчук О. А., Демкова М. С. Правова допомога: зарубіжний досвід та пропозиції для України. Київ: Факт, 2004. $504 \mathrm{c}$. 


\section{Кримінальне право, кримінальни ЗАРУБІЖНИЙ ДОСВІД РЕГААМЕНТАЦІЇ КРИМІНААЬНОЇ ПРОЦЕСУАЛЬНОЇ ДІЯАЬНОСТІ АДВОКАТА-ПРЕДСТАВНИКА ПОТЕРПІАОГО}

У статті розглянуто соціально-правовий статус адвоката за законодавством деяких зарубіжних країнах з визначенням особливостей його діяльності. Проаналізовано кримінальне процесуальне законодавство деяких зарубіжних країн. Систему кримінального судочинства більшості країн Європи і Північної Америки розподілено на країни, що використовують англосаксонську модель кримінального судочинства, законодавство яких не знає такого учасника кримінального процесу як потерпілий та континентального змішаного кримінального процесу, у якому кримінально-процесуальне законодавство Німеччини детальніше, ніж законодавство Франції, визначає правовий статус адвоката-представника потерпілого i, на відміну від останнього, наділяє його такими процесуальними правами, які відсутні в особи, яку представляють.

За результатами порівняння законодавства України та деяких зарубіжних країн щодо участі захисника в стадії досудового розслідування констатовано, що їх положення подібні. Це пояснюється поглибленням міжнародного співробітництва в боротьбі зі злочинністю, розвитком принципу верховенства права, захисту прав людини, підсиленням демократичних стандартів у кримінальному судочинстві, широким застосуванням правових позицій Европейського Суду 3 прав людини. Встановлено, що правова регламентація діяльності адвокатів у форматі Свропейського Союзу грунтується на вимогах національного законодавства цих країн. Схожий підхід застосовано і в Україні.

3'ясовано, що спільними рисами законодавства України й деяких зарубіжних країн є наявність норм, що передбачають: визначення особи, яка може бути захисником у кримінальному процесі; вимоги на підтвердження повноважень захисника; обов'язки і права захисника; порядок залучення захисника; випадки обов'язкової участі захисника; умови відмови, заміни, відсторонення захисника; можливість призначення захис- ника, порядок і умови такого призначення. Залежно від структури кримінального процесу (відсутність стадії досудового розслідування), повноваження адвоката суттєво різняться.

Системи кримінального судочинства більшості країн Європи і Північної Америки стосовно ролі і обсягу процесуальних прав потерпілого поділяються на дві основні групи - англосаксонська модель кримінального судочинства (Великобританія, Ірландія, США, Канада) та континентальна системи кримінального судочинства (Франція, ФРН). Зміцнення процесуального статусу потерпілого і його представника 6 новітньою загальносвітовою тенденцією. Розвинені держави бачать вирішення проблеми захисту прав жертв злочину не в останню чергу в консультуванні і наданні їм юридичної допомоги. При цьому у цих країнах по-різному підходять до визначення процесуального статусу адвоката-представника потерпілого. Найчастіше його процесуальні можливості визнаються ідентичними процесуальним правам того, що представляється (Франція, Австрія). Виключення складає кримінально-процесуальне законодавство ФРН, де адвокат-представник потерпілого має особливий статус, що включає ряд важливих повноважень, які відсутні у самого потерпілого

Ключові слова: адвокат, представник потерпілого, кримінально-процесуальна діяльність, розслідування, надання правової допомоги.

\section{FOREIGN EXPERIENCE IN REGULATING THE CRIMINAL PROCEEDINGS OF THE VICTIM'S LAWYER}

The article considers the social and legal status of a lawyer under the laws of some foreign countries with the definition of the peculiarities of his activity. The criminal procedural legislation of some foreign countries is analyzed. The criminal justice system of most European and North American countries is divided into countries that use the Anglo-Saxon model of criminal justice, whose legislation does not recognize such a participant in the criminal process as the 


\section{АНОТАЦІЯ}

у статті розглянуто соиіально-правовий статус адвоката за законодавством деяких зарубіжних країнах з визначенням особливостей його діяльності. Систему кримінального судочинства більшості краӥн Европи і Північної Америки розподілено на країни, що використовують англосаксонську модель кримінального судочинства, законодавство яких не знає такого учасника кримінального процесу як потерпілий та континентального змішаного кримінального процесу, у якому кримінальне процесуальне законодавство визначає правовий статус адвоката-представника потерпілого, а деяких 3 них наділяе його такими прочесуальними правами, які відсутні в особи, яку представляють.

За результатами порівняльного дослідження встановлено, що законодавство Украйни та зарубіжних краӥн щодо участі захисника в стадї̈ досудового розслідування подібні. Це пояснюється поглибленням міжнародного співробітництва в боротьбі зі злочинністю, розвитком принципу верховенства права, захисту прав людини, підсиленням демократичних стандартів у кримінальному судочинстві, широким застосуванням правових позииій Європейсъкого Суду з прав людини. Встановлено, що правова регламентаиія діяльності адвокатів у борматі Европейсъкого Союзу грунтується на вимогах начіонального законодавства изих крайн.

Ключові слова: адвокат, представник потерпілого, кримінально-прочесуальна діяльність, розслідування, надання правової допомоги.

victim and the continental mixed criminal process, in which German criminal procedure defines more detail than French the legal status of the lawyer-representative of the victim and, unlike the latter, endows him with such procedural rights that the person he represents does not have.

According to the results of the comparison of the legislation of Ukraine and some foreign countries regarding the participation of the defense counsel in the stage of pre-trial investigation, it was stated that their provisions are similar. This is due to the deepening of international cooperation in the fight against crime, the development of the rule of law, protection of human rights, strengthening democratic standards in criminal proceedings, the wide application of the legal position of the European Court of Human Rights. It is established that the legal regulation of lawyers in the format of the European Union is based on the requirements of the national legislation of these countries. A similar approach is used in Ukraine.

It was found that the common features of the legislation of Ukraine and some foreign countries are the existence of rules that provide for: the definition of a person who can be a defender in criminal proceedings; requirements for confirmation of the powers of the defender; duties and rights of the defender; the procedure for attracting a lawyer; cases of mandatory participation of defense counsel; conditions of refusal, replacement, removal of the defender; the possibility of appointing a defender, the procedure and conditions of such appointment. Depending on the structure of the criminal process (absence of a pre-trial investigation stage), the powers of a lawyer differ significantly.

The criminal justice systems of most European and North American countries regarding the role and scope of procedural rights of the victim are divided into two main groups - the Anglo-Saxon model of criminal justice (UK, Ireland, USA, Canada) and the continental criminal justice system (France, Germany). Strengthening the procedural status of the victim and his representative is the latest global trend. Developed countries see the solution to the problem of protecting the rights of victims of crime, not least in counseling and providing them with legal assistance. At the same time, these countries have different approaches to determining the procedural status of the victim's lawyer. Most often, its procedural possibilities are recognized as identical to the procedural rights of what is represented (France, Austria). The exception is the criminal procedure legislation of Germany, where the lawyerrepresentative of the victim has a special status, which includes a number of important powers that are not available to the victim

Keywords: lawyer, victim's representative, criminal procedure activity, investigation, legal aid. 